Research Report No. 41/2008

\title{
The Transformation of Chinese Enterprise Income Tax: Internationalization and Chinese Innovations
}

Jinyan Li

Osgoode Hall Law School of York University, JLi@osgoode.yorku.ca

He Huang

Follow this and additional works at: http:/ / digitalcommons.osgoode.yorku.ca/clpe

\section{Recommended Citation}

$\mathrm{Li}$, Jinyan and Huang, He, "The Transformation of Chinese Enterprise Income Tax: Internationalization and Chinese Innovations" (2008). Comparative Research in Law \& Political Economy. Research Paper No. 41/2008.

http://digitalcommons.osgoode.yorku.ca/clpe/210 


\section{J inyan Li \& He Huang}

The Transformation of Chinese Enterprise Income Tax: Internationalization and Chinese Innovations

This article has been published in (2008) Bulletin for International Fiscal Documentation

EDTORS: Peer Zumbansen (Osgoode Hall Law School, Toronto, Director, Comparative Research in Law and Political Economy, York University), J ohn W. Cioffi (University of California at Riverside), Lindsay Krauss (Osgoode Hall Law School, Toronto, Production Editor) 

CLPE Research Paper 41/2008

Vol. 04 No. 08 (2008)

\title{
Jinyan Li and He Huang
}

\section{THE TRANSFORMATION OF CHINESE ENTERPRISE INCOME TAX: INTERNATIONALIZATION AND CHINESE INNOVATIONS}

\begin{abstract}
This article reviews the major elements of the enterprise income tax (EIT) system in China and examines the dynamic relationship between international norms and the local Chinese context. After some introductory remarks, the article discusses the fundamental principles, concepts and structural elements of the EIT system and examines its main transformative aspects in terms of form, process and substantive provisions. The article also considers the extent to which international tax norms, China's policy concerns and traditional issues play a role in the new system. The article concludes with some observations on international tax norms.
\end{abstract}

Keywords: China, Corporate Income Tax, tax norms, tax avoidance, tax policy

JEL classification: K33, K34

Author Contact:

Jinyan Li

Osgoode Hall Law School, York University 4700 Keele St, Toronto Ontario, M3J 1P3

Email: jli@osgoode.yorku.ca

He Huang

Osgoode Hall Law School, York University

4700 Keele St, Toronto Ontario, M3J 1P3

Email: hehuang@osgoode.yorku.ca 


\title{
The Transformation OF ChInese EnTERPRise INCOME TAX: INTERNATIONALIZATION AND CHINESE INNOVATIONS
}

\author{
Jinyan $\mathrm{Li}^{*} \&$ He Huang ${ }^{* *}$
}

\section{INTRODUCTION}

The Chinese enterprise income tax (EIT) system has undergone major reforms over the past 28 years. A western style income tax was first introduced in 1980 - the Chinese-foreign Joint Venture Income Tax (JVIT) ${ }^{1}$ Foreign tax terminologies, structures and concepts found their way into the JVIT, but the "Chinese characteristics" were overwhelmingly present. Since 1980, the trend has been more "internationalization" as the Chinese economy moves closer to a "market" system. To the Chinese, because market was originated from the West and the market demands "rational" laws, ${ }^{2}$ which are predominantly "Western" laws, it is important to "transplant" Western laws to China and to harmonize Chinese laws with international norms. Tax law directly affects the market and corporate tax is less politically and culturally sensitive (as compared to personal income tax or sales tax), so the process of "internationalization" was more speedy and notable. ${ }^{3}$ This is the case in the promulgation of the EIT Law ${ }^{4}$ and EIT Regulations ${ }^{5}$ (collectively referred to as “EIT Legislation”).

\footnotetext{
* Professor, Osgoode Hall Law School, York University, Canada; and Senior Fellow, Taxation Law and Policy Research Institute, Monash University, Australia.

** LL.M. Candidate at Osgoode Hall Law School, York University

${ }^{1}$ The Income Tax Law of the People's Republic of China Concerning Joint Ventures with Chinese and Foreign Investment, adopted by National People's Congress and promulgated on September 10, 1980. It was abolished with the promulgation of Income Tax Law of the People's Republic of China for Enterprises with Foreign Investment and Foreign Enterprises, promulgated by the National People's Congress on 9 April 1991 (hereinafter "FIET Law").

${ }^{2}$ See Jianfu Chen, "The Transformation of Chinese Law: From Formal to Substantial" (2007) Vol.37, No.2, Hong Kong Law Journal, available at http://ssrn.com/abstract=1099507, last visited on April 27, 2008, at 709.

${ }^{3}$ Ibid.
} 
The EIT legislation is a product of hybridizing international tax norms and indigenous Chinese rules. An earlier article published in the Bulletin ${ }^{6}$ provides a more detailed account of the legislative background for the EIT Law. This article reviews the major elements of the EIT system and examines the dynamic relationship between international norms and the local Chinese context.

Following this Introduction, Part 2 of the article discusses the fundamental principles, concepts and structural elements of the EIT system. Part 3 examines the main transformative aspects of the new tax system in terms of form, process and substantive provisions. Part 4 discusses the extent to which international tax norms, Chinese policy concerns and traditional issues play a role in the new system. The article concludes with some observations on international tax norms.

\section{THE NEW ENTERPRISE INCOME TAX SySTEM}

\section{A. OVERVIEW}

The process that culminated in the promulgation of the EIT Law was lengthy (13 years) and relatively transparent (earlier drafts were widely debated and commented on). The structure and substantive provisions of the EIT legislation are more sophisticated than its predecessors. The explanatory notes on the EIT Law and EIT Regulations by the State Administration of Taxation (SAT) are detailed and insightful, and more

${ }^{4}$ Enterprise Income Tax Law of the People's Republic of China, promulgated by the $5^{\text {th }}$ Session of the $10^{\text {th }}$ National People's Congress, 16 March 2007 (hereinafter referred to as "EIT Law"). The Chinese text of the EIT Law is available at the State Administration of Taxation web site: www.chinatax.gov.cn.

${ }^{5}$ Implementation Regulations of Enterprise Income Tax Law of the People's Republic of China, promulgated by Decree No.512 of the State Council on December 6, 2007, effective January 1, 2008 (hereinafter referred to as “EIT Regulations”). The Chinese text of the EIT Regulations is available at: www.chinatax.gov.cn.

6 Jinyan Li, "Fundamental Enterprise Income Tax Reform in China: Motivations and Major Changes” Vol. 61, November 12, 2007, Bulletin for International Taxation 519528. 
importantly, available to the public. ${ }^{7}$ It is indeed heartening to see such level of expertise and openness being developed in China in such short period of time. ${ }^{8}$

As explained in more detail elsewhere, ${ }^{9}$ the EIT was introduced to achieve the following objectives: to ensure equitable taxation of all enterprises by ending systematic and serious discrimination against Chinese-owned enterprises; to promote overall, sustainable development of China's economy; to be consistent with international tax norms and practices; and to improve efficiency in tax administration. ${ }^{10}$

One major tax policy objective is neutrality. All enterprises, irrespective of ownership, are subject to the same rules. By taxing foreign-invested enterprises (FIEs) similarly as domestic-invested enterprises (DIEs), the EIT reflects capital-import neutrality. The EIT legislation also promotes capital-export neutrality by taxing residents on their worldwide income with a credit given for taxes paid in respect foreign direct income and indirect income (i.e., dividends from foreign corporations).

Another policy objective is the protection of China's tax base. The EIT legislation contains a number of new anti-avoidance rules applicable to cross-border transactions, ${ }^{11}$ a general anti-avoidance rule (GAAR), as well as new rules to secure Chinese source-based tax jurisdiction (e.g., the meaning of resident, permanent establishment, withholding taxes, and source rules).

A third major policy objective is to use tax policy as an instrument in promoting sustainable economic development. Attracting FDI to China remains a key policy concern. Instead of providing FDI-specific tax incentives, the EIT adopts an internationally competitive rate. ${ }^{12}$ The tax

\footnotetext{
${ }^{7}$ They are published on the SAT website and tax newspapers and magazines.

${ }^{8}$ One of the authors of this article was involved in training Chinese tax officials in early 1990s and has been a keen observer of Chinese tax developments since the mid-1980s.

${ }^{9} \mathrm{Li}$, supra note 6 .

${ }^{10}$ Renqing Jin, Minister of Finance, “Explanation on Draft Enterprise Income Tax Law”. The full text of the speech in English is available at www.chinaembassy.org/eng/gyzg/t30221.htm (visited on 31 July 2007).

${ }^{11}$ EIT Law, supra note 4, Arts.41-48; EIT Regulations, supra note 5, Arts.109-123.

${ }^{12}$ The Minister of Finance stated (supra note 10): [T] he level of enterprise income tax
} 
incentives are targeted at investments in small enterprises, high-tech enterprises, and projects in agriculture, forestry, animal husbandry, fisheries, job-creation, public infrastructure, environmental protection, conservation of energy and water resources, research and development, and transfers of technology. ${ }^{13}$

The EIT Law and Regulations are organized into eight chapters: (1) general principles that basically deal with the issue of "liability for tax", i.e., who is a taxpayer under the EIT and the scope of tax liability for resident and non-resident taxpayers; (2) computation of taxable income; (3) computation of tax payable; (4) tax incentives; (5) withholding of taxes at source; (6) special tax adjustments, which contain anti-avoidance rules that empower the tax authorities to make special adjustments to the tax liability determined under the "normal" rules; (7) tax administration; and (8) supplementary provisions.

\section{B. LIABILITY TO TAX}

Enterprises are subject to the EIT if they are residents or non-residents earning Chinese-source income. Resident enterprises are subject to tax on their income from inside and outside China, whereas non-resident enterprises are subject to tax only on their Chinese-source income.

\section{1. "ENTERPRISE"}

The term "enterprise" is undefined in the EIT legislation. According to the SAT Explanatory Notes on the EIT Law, an "enterprise" includes, but is not limited to, a "corporation". The key is whether an entity is a "legal

rates in the world, especially the neighbouring countries (regions), has to be taken into account. The average enterprise income tax rate is 28.6 percent in 159 countries (regions) around the world in which an enterprise income tax is applied, while that in China's 18 neighbouring countries (regions) is 26.7 percent. The rate of 25 percent set in the Draft is relatively low in the world and will be conducive to enhancing enterprise competitiveness and attracting foreign investment.

${ }^{13}$ EIT Law, supra note 4, Art. 27. 
person” under Chinese civil law. ${ }^{14}$ In addition, some non-profit entities are treated as "enterprises" for the purposes of the EIT. On the other hand, a sole proprietorship enterprise or a partnership established in China is specifically excluded from the meaning of "enterprise" (EIT Law, Art.1). Sole proprietors are subject to the Individual Income Tax. ${ }^{15}$ A Chinese partnership is treated as a flow-through entity and its income or loss is taxable to the partners. A foreign partnership, in contrast, is taxable as an enterprise under the EIT (EIT Regulations, Art.3).

Why treating domestic and foreign partnerships differently? According to the SAT Explanatory Notes on the EIT Law, this rule is needed to prevent double taxation and to protect the Chinese tax base. In the case of a Chinese partnership, the assumption is that Chinese partners are taxable under the Individual Income $\operatorname{Tax}^{16}$ (in the case of an individual partner) or the EIT (in the case of an enterprise partner). Treating a Chinese partnership as a conduit eliminates double taxation of the income earned through the partnership. If a foreign partnership is not taxed as an enterprise, then its income would be free from the EIT and the foreign partners would not be taxable in China.

\section{2. "RESIDENCE"}

For the first time in Chinese enterprise income taxation, "residence" is used as a basis for determining tax jurisdiction. The term "resident enterprise" is defined as an enterprise established in China, or an enterprise that is created under foreign laws but has a place of effective management in China (EIT Law, Art.2). "An enterprise established in China” refers to "an enterprise, non-profit entity, social organization and another type of entity that earns income and is created in accordance with Chinese laws or administrative regulations" (EIT Regulations, Art.3). As such, the test of residency is a combination of place of incorporation and

${ }^{14}$ General Principles of the Civil Law of the People's Republic of China, adopted at the $4^{\text {th }}$ Session of the $6^{\text {th }}$ National People's Congress and promulgated on April 12, 1986, and effective as of January 1, 1987, Article 36-53 .

${ }^{15}$ Individual Income Tax Law of the People's Republic of China, adopted at the $3^{\text {rd }}$ Session of the $5^{\text {th }}$ National People's Congress on September 10, 1980 and promulgated on September 10, 1980; revised in 1991 and 1999.

${ }^{16}$ Ibid. 
place of effective management.

The term "place of effective management" refers to "the place that executes substantial and overall management and control over the production and business operations, personnel, finance, properties and other matters. According to the SAT Explanatory Notes on the EIT Regulations, the "place of effective management test" requires the following three conditions be met:

(1) The management must be "effective or substantial," having real impact on the business operations of the enterprise. This is to be contrasted to a "rubber stamp". A place of effective management is often different from the formal place of governance, which is mostly created for tax avoidance purposes. It is not limited to the place where the board of directors holds its meetings. Ultimately, it is a question of fact. In the absence of specific, objective criterion, the test is based on the place where the economic nexus is strongest. This is consistent with overall "substance over form" principle.

(2) The management and control must be "comprehensive". If the management covers only one segment, or a non-essential part, of the enterprise's business, it does not meet the test.

(3) The management and control must affect production and business operations, personnel, finance, and assets (substantive business elements). This is the most essential condition for the test. If a foreign enterprise is formally managed and controlled by a place outside China but the decisions about substantive business elements of the enterprises are made in China, the place of effective management is China.

The SAT is expected to publish detailed measures for the determination of place of effective management. Generally speaking, the place of effective management is determined by the place of actually management on the basis of the facts and circumstances of the case. The SAT is prepared to go beyond the common-law test in Anglo-Saxon countries. ${ }^{17}$

${ }^{17}$ For more discussion on corporate residence, see Robert Couzin, Corporate Residence and International Taxation (IBFD, 2002). 


\section{3. "ESTABLISHMENT" OR "SITE"}

If a non-resident enterprise has an "establishment or site" in China, any income that is attributable to such establishment or site is taxable in China. The term "establishment" is defined to be "an establishment or site for carrying on production and business operations in China" (EIT Regulations, Art 5). It specifically includes:

- a place of management, business, or office (or place of administration);

- a factory, farm, or a place of extraction of natural resources;

- a place for providing services. "Services" include transportation, warehousing, consulting, scientific research, technical services, education and training, restaurant and hotels, agency, travel, entertainment, and processing;

- a place of construction, installation, assembly, repair, and exploitation (including building site, ports, place of exploration);

- a place of conducting other production and business activities.

This is very close to the "fixed place of business" type of permanent establishment in the context of Article 5 of the OECD Model Tax Convention.

In addition, an agent is deemed to be an establishment or site of a nonresident enterprise if the agent is authorized to carry on production or business activities in China on behalf of the non-resident enterprise, such as frequently signing contracts, or storing or delivering goods on behalf of the non-resident. This is similar to the "agency permanent establishment" in the context of Article 5 of the OECD Model Tax Convention. According to the SAT Explanatory Notes on EIT Regulations, an agent can be an enterprise or an individual in China. The activities of the agent must be "frequent" or "habitual", not incidental or short-term. The question of what constitute "frequent" or "habitual" activities is a practical one that needs to be addressed in a flexible manner.

\section{SOURCE RULES}

Chinese-source income that is not effectively connected to an 
establishment or site is generally subject to withholding tax at the rate of $20 \%$. The main source rules are contained in Article 7 of the EIT Regulations, which include the following:

- The source of income from the sale of goods is the place of the sale transaction. The SAT states in its Explanatory Notes on EIT Regulations, according to international tax norms, the place of a sale transaction is often the seller's place of business, or the place of the customer if the goods are delivered to the buyer, or a place specified in the purchase and sale agreement.

- The source of service fees is the place where service activities occur. According to the SAT Explanatory Notes on EIT Regulations, where a foreign enterprise provides financial insurance services to Chinese residents and collects premiums from such residents, the source is China.

- The source of income from the transfer of property is determined in three different scenarios: (a) in the case of immovable property, the source is the location of the property; (b) in the case of movable property, establishment or site, the source is determined by the place of the owner of immovable property or the location of the establishment or site; (c) in the case of shares and other forms of equity investment, the source is determined by the residence of the company whose equities are transferred.

- The source of dividends and bonuses is the determined by the residence of the corporation that pays the dividends and bonuses.

- The source of interest, rents and royalties is determined the location of the payer. In cases where the payments are borne by an establishment or site, the source is determined by the location of the establishment or site.

- The source of other types of income will be determined by the tax authorities or the Ministry of Finance.

Income that is sourced outside China but effectively connected to a Chinese establishment or site is deemed to be Chinese-source income (EIT Law, Art.3; EIT Regulations, Art.8). The SAT Explanatory Notes on EIT Regulations identify two scenarios. One is the case where income is earned on equity or debt investments owned through the establishment or 
site. For example, a non-resident enterprise makes equity or debt investments in another enterprise through an establishment or site in China and the dividend or interest income earned is effectively connected income. Another scenario is the case where income is earned through assets owned, managed or controlled by an establishment or site. For example, where a non-resident enterprise leases a real property located inside or outside China, the rental income is effectively connected to an establishment or site in China if the property is owned, managed or controlled by the establishment or site.

These source rules are obviously intended to protect China's tax base as a net capital-importing country. Enforcing the source rules will be difficult in some cases, such as where one non-resident sells shares of Chinese resident companies outside China to another non-resident.

\section{TAXABLE INCOME}

\section{FUNDAMENTAL PRINCIPLES}

The bulk of the EIT Law (Arts.5-21) and EIT Regulations (Arts.9-51) is devoted to the computation of taxable income. The following principles seem to underlie these rules:

a) The determination of taxable income is primarily a legal question. Although financial accounting is often the basis for the computation of income or loss, the ultimate determination must be governed by the provisions of the EIT Law and EIT Regulations (EIT Law, Art.21). These legal provisions override any inconsistent financial accounting principles.

b) Revenues and expenses must be recognized in accordance with the accrual method of accounting (EIT Regulations, Art.9).

c) The principle of truthfulness requires revenues and expenses be supported by evidence (typically invoices or receipts).

d) The principle of "substance over form" requires transactions be characterized for tax purposes in accordance with economic substance, not the legal form.

e) The principle of realization requires income be recognized only when it is "realized", that is, when the income-earning transaction is "realized" or "completed" (SAT Explanatory 
Notes on EIT Regulations).

The basic formula for computing taxable income is: "Taxable income = total revenue - excluded income - exempt income - deductions - loss carryover". Each of the elements is discussed briefly below.

\section{REVENUE}

Revenue refers to the revenue or income from various sources in cash or in kind. These sources include sale of goods, providing services, transferring properties, dividends, interest, rent, royalties, donations and other types of revenues. "Other revenue" includes revenue derived from asset surplus such as the discovery of unbooked assets, amounts payable that cannot be settled, collections from accounts receivable which were previously written off as bad debts, revenue from debt-restructuring, subsidies, penalty income from breach of contracts, exchange gains, etc (EIT Regulations, Art.22). Revenues received in kind must be converted into cash on the basis of the fair market value of the property or services (EIT Regulations, Art.13).

Non-taxable or excluded income includes funds allocated by the government finance departments, fees collected for services provided by government agencies, non-profit enterprises or social organizations in accordance with the relevant laws and regulations. In addition, other amounts designated as non-taxable by the SAT or Ministry of Finance (EIT Regulations, Art.26). According to the SAT Explanatory Notes, such "open-ended" category is to accommodate the rapid social changes in China, especially the rising role of non-profit organizations that may charge fees for their activities.

Exempt income includes interest on state bonds, dividends received from a resident company, dividends that are effectively to an establishment or site of a non-resident enterprise, and income earned by non-profit organizations ${ }^{18}$ that meet the qualifying conditions (EIT Law, Art.26). ${ }^{19}$

${ }^{18}$ EIT Regulations, supra note 5, Art. 84. An eligible non-profit organization must: (1) be registered as a non-profit organization; (2) engage in carrying on public or non-profit activities; (3) use its income, except the deduction of reasonable expenses for relevant 
Exempting dividends effectively connected with a Chinese establishment is intended to prevent economic-double taxation of the income earned by a non-resident in China. However, this exemption does not make sense because China imposes withholding tax on dividends (EIT Law, Art.37) and China does not yet have a "branch tax". It creates in-equitable treatment between a non-resident investor investing directly in a Chinese company or investing through a Chinese branch.

\section{DEDUCTIONS}

Costs, expenses, taxes, losses and other outlays are deductible in computing taxable income. This reflects the principle that income is a net concept. According to the SAT Explanatory Notes, for an item to be deductible, it must be "truthful" or "real" (zhenshi xing), legal, and reasonable. The expense must have been incurred and supported by evidence. Any unlawful expenditures, even if deductible under accounting principles, cannot be deducted in computing taxable income. The reasonable test requires that the expense be "normal" and "necessary" for the purpose of earning income. For mixed business and personal expenses, a reasonable allocation must be made.

The deductible costs and expenses are generally self-explanatory. These include the cost of wages, salaries, bonuses, as well as contributions to basic (mandatory) pension plans, basic medial insurance plans, basic unemployment insurance plans, workers' compensation plans, familyplanning insurance plans, housing provident funds, and other social insurance plans. Contributions to supplementary insurance plans, medical insurance plans and other plans approved by State Council are deductible. $^{20}$

activities, in the public or non-profit activities; (4) not distribute property; (5) after the termination, must use the remaining assets for public or non-profit purposes. In addition, the founder of the non-profit organization shall not have any right to the property of the organization and the expense of salary shall be controlled in certain proportion.

19 Other items of income may be exempted under Article 27 of the EIT Law.

20 See Jinyan Li, "Enterprise Annuities in China: Regulatory Framework, Practical Challenges, and International Opportunities” (2005) No.52 International Pension Lawyer 
Financing expenses incurred for income-earning purposes that are not required to be capitalized are deductible. Interest and other financing expense must be capitalized during the period when the borrowed money is used to acquire or construct a fixed asset or intangible asset, or an inventory that require at least 12 months to be constructed, but only during the period of acquisition or construction.

The deduction of certain types of expenses is capped. Examples are:

- $60 \%$ of entertainment expenses are deductible up to $0.5 \%$ of the sale or business revenue of the year (EIT Regulations, Art.43);

- advertising expenses are deductible up to $15 \%$ of the annual sale or business revenue (EIT Regulations, Art. 44);

- expenses on promoting workers' welfare are deductible up to 14 of the total wages and salaries (EIT Regulations, Art.40); and

- expenses on workers' training and education are deductible up to $2.5 \%$ of the total wages and salaries (EIT Regulations, Art. 42).

Deductible "taxes" refer to non-income taxes, such as consumption taxes, business tax, resource tax, education surtax, real estate tax, vehicle and vessel license tax, and stamp duties, but not VAT borne by customers. "Losses" refer to losses from devaluation of business assets, lost assets, bad debts, and similar items. Donations for the purpose of public relief are deductible up to $12 \%$ of the annual profit.

Non-deductible items include dividends, taxes paid under the EIT Law, late-payment penalties, fines and penalties, sponsorships, un-verified reserves, and other amounts incurred for non-income earning purposes.

As a general principle under the EIT Law, a branch is not a separate enterprise and its income or losses are part of the total income or losses of the enterprise. However, when an enterprise carries on business outside China through a foreign branch, the enterprise is prohibited from offsetting

39-53; "Enterprise Annuities and Tax Policy in China: Engaged, but Not Yet Married" (2005) Vol.59, No.12, Bulletin for International Fiscal Document 527-533. 
the branch's loss against its income (EIT Law, Art.17). The SAT Explanatory Notes provides two rationales for this surprising rule: one is to protect the Chinese tax base because a taxpayer may use foreign branches fraudulently to avoid Chinese taxes and such behaviour is difficult for the Chinese tax authorities to manage. Another rationale is to respect the "territorial principle", that is foreign losses should offset foreign income. For different policy reasons, intra-company payments of management fees, rents, royalties, and interest (other than banks) are not deductible (EIT Regulations, Art.49). On the other hand, expenses paid by a Chinese establishment or site to its foreign head-office are deductible if the expenses are incurred for income-earning purposes and there is sufficient evidence proving the scope and amount of the expenses and method of allocation is reasonable (EIT Regulations, Art.50). This is consistent with Article 7 of the OECD Model Tax Convention.

\section{CAPITAL AsSETS AND INVENTORIES}

Generally speaking, it is the "historical cost", or the laid-out cost, that is deductible. The cost of fixed assets is depreciated under a straight-line method (EIT Regulations, Art.60):

- 20 years for buildings,

- 10 years for aircrafts, trains, vessels, machinery, and other production equipment;

- 5 years for other instruments, tools, furniture and other assets used in production and business activities;

- 4 years for aircrafts, trains and vessels used in transportation; and

- 3 years for electronic equipment.

Special rules will be stipulated by the government for expenditures and depreciation of fixed assets in respect of enterprises engaged in the exploration of oil, gas and mineral resources (EIT Regulations, Art.61).

The period of amortization is 10 years for biological assets in forestry production and 3 years for those used in livestock production (EIT Regulations, Art.64). The cost of acquiring intangible assets (including patents, trademarks, copyrights, land-use rights, non-patented 
technologies, goodwill, etc.) is generally amortized during a period of not less than 10 years. However, the cost of purchasing goodwill is deductible when the entire business of an enterprise is sold or the enterprise is liquidated (EIT Regulations, Arts.65-67).

Long-term pre-paid expenses are amortized by instalments during a period of 3 years (EIT Regulations, Art.70). The cost of acquiring investment assets is recognized only when the assets are transferred or disposed of (EIT Regulations, Art. 71).

The cost of goods sold is also deductible, which can be determined by using the "first-in, first out", weighted average, or specific tracing method, but not "last-in, first out" method. The LIFO method cannot be used because it tends to "increase the cost of goods sold and reduce profit" during inflationary times (SAT Explanatory Notes on EIT Law).

When capital assets are disposed of, the net asset value is deductible in computing taxable income (EIT Law, Art.16). In the case of depreciable assets, this value represents the un-depreciated cost of the assets.

Losses can be carried forward, not back, for 5 years (EIT Law, Art.18). There is no distinction between capital losses and non-capital losses as capital gains are fully taxable.

\section{TAXABLE INCOME OF NON-RESIDENTS}

The taxable income of a non-resident enterprise carrying on business in China through an establishment or site is computed in accordance with the rules discussed above. In other words, taxable income is net of deductible costs and expenses. The taxable income of other non-resident enterprises, however, is gross.

Taxable income earned from Chinese-source dividends, interest, rent or royalties is the full amount received (EIT Law, Art.19). According to the SAT Explanatory Notes on EIT Law, a non-resident enterprise is also liable to Chinese tax on the gross amount of fees for services provided to enterprises or individuals inside China or for providing foreign insurance to enterprises or individuals in China. The service fees and insurance 
premiums are treated as Chinese-source income because the payer is in China and taxable on a gross basis.

\section{TAX PAYABLE}

The amount of tax payable is defined to be the amount of taxable income, multiplied by the applicable tax rate, less tax credits, reductions or exemptions (EIT Law, Art.22).

\section{RATES}

The standard rate is 25\% (EIT Law, Art.4). A lower rate of $20 \%$ applies to qualified small, low-profit enterprises, ${ }^{21}$ and a further lower rate of $15 \%$ applies to "key state-supported, new and high-tech enterprises." 22 (EIT Law, Art.28)

The 25\% standard rate was believed to be internationally competitive. ${ }^{23}$ Small, low-profit enterprises are believed to be strategically important in creating jobs and stimulating economic growth in China, but their tax capacity is limited. Therefore, in order to support such enterprises, a lower rate is available to them. High-tech enterprises have received preferential treatment under the previous tax system, especially those invested by foreign companies or located in designated areas. The $15 \%$ reduced rate is now applicable to all qualifying enterprises, irrespective of ownership or location.

\footnotetext{
21 “Small, low-profit enterprise” is defined under Art.92 of the EIT Regulations as an enterprise that meets the following requirements: (1) its business is in non-restricted or non-prohibited sectors; (2) in the case of an industrial enterprise, its annual taxable income does not exceed CNY 300,000, the number of employees does not exceed 100 people, and the value of assets does not exceed CNY 30 million; (3) in other cases, its annual taxable income does not exceed CNY 300,000, the number of employees does not exceed 80 people, and the value of assets does not exceed CNY 10 million.

${ }^{22}$ EIT Regulations, supra note 5, Art.93

${ }^{23} \mathrm{Jin}$, supra, note 10 .
} 


\section{TAX CREDITS}

A credit is dollar-for-dollar deduction in computing tax liability. There are two types of credits recognized by the EIT Law: (a) foreign tax credit to prevent international double taxation (EIT Law, Art.23); and (b) tax credits as a form of subsidies for preferred investments, such as venture capital (EIT Law, Art.31) and investment in environmental protection, energy and water conservation, and production safety (EIT Law, Art. 34).

\section{E. TAX INCENTIVES}

The EIT legislation provides "tax incentives to industries and projects that are specifically supported and encouraged by the state” (EIT Law, Art.25). Tax preferred enterprises include: small, low-profit enterprises, high-tech enterprises, and non-profit enterprises. Tax favoured investments are those in agriculture and fishing, infrastructure, venture capital, environmental protection and production safety, and investments in ethnic minority regions, which are often less-developed regions in China.

Tax incentives take a variety of forms, including:

- full or partial exemption (with or without temporal limitations),

- tax rate reduction (see above),

- accelerated depreciation,

- imputed additional deductions, and

- tax credit.

Different forms of tax incentives are used to deliver different degree of "subsidies". For example, a permanent exemption is available for interest on state bonds, inter-corporate dividends and income of eligible non-profit enterprises. A time-limited exemption applies to income from agricultural projects, key infrastructure projects, and environmental protection and energy/water conservation projects, or income from transfer of technology (EIT Law, Art.27). Full exemption is applicable to agricultural income from growing vegetables, medicinal herbs, animals, but a half exemption applies to income from growing flowers, tea, other beverage crops and spice crops, certain fishery, etc. (i.e., 50\% of eligible income is exempt from tax) (EIT Regulations, Art.86). A 3-year full exemption and 3-year 
half-exemption, beginning in the year in which the taxpayer earns its first amount of revenue from such qualified project is applicable to income from environmental protection and infrastructure projects (EIT Regulations, Arts.87 and 88). In addition, a permanent partial exemption (10\% of qualified income) applies to income derived from the production of products by way of comprehensive utilization of resources is included in computing income; this is referred to as the "reduced income inclusion method" because only $90 \%$ of the income is included in computing taxable income) (EIT Law, Art. 33 and EIT Regulations, Art.99).

The method of imputed deductions is used to encourage certain expenditures, such as research and development expenditures, cost on hiring disabled workers. The tax deductible amount is deemed to be $150 \%$ of the actual expenditure on research and development and 200\% of the actual wages paid to disabled workers (EIT Regulations, Art.95). This is considered to be more effective than income exemption because the taxpayer can get the subsidy as soon as the expenditure is made (whether or not there is any income) and the amount of subsidy increases as the amount of the eligible expense.

High-tech enterprises receive several types of tax incentives, including: (a) reduced tax rate of 15\% (EIT Law, Art.28); (b) exemption of income from transfer of technology (EIT Law, Art. 27); ${ }^{24}$ (c) additional deduction for research and development expenses (i.e., $150 \%$ of actual expenditure is deductible as current expenses or amortized as capital expenditures) (EIT Law, Art.30 and EIT Regulations, Art.95); (d) accelerated depreciation (EIT Law, Art.32 and EIT Regulations, Art.98); and (e) special deductions for eligible investors of high-tech enterprises. If a venture capital enterprise invests in the shareholdings of a private small or medium size new and high-tech enterprise by stock for two years or more, $70 \%$ of the amount of the investment may be deductible against the taxable income. The deductions can be carried over to the following tax year (EIT Law, Art. 31 and EIT Regulations, Art. 97).

The so-called "green” industries or projects may qualify as "high-tech" enterprises. In addition, $10 \%$ of the income is excluded from income if it is

${ }^{24}$ If the value of technology transfer does not exceed CNY 5 million, this income is exempt from tax. Any excess shall be subject to a $50 \%$ tax reduction of normal tax rate. 
derived from products made by way of "comprehensive utilization of resources" in accordance with the standard published by the government (EIT Regulations, Art.99). 10\% of the expenditures on purchasing qualified equipment specifically for the purpose of protecting the environment are creditable against income tax. This credit could be carried forward for 5 years (EIT Law, Art.34; EIT Regulations, Art.100).

\section{F. INTERNATIONAL TAX ISSUES}

\section{JURISDICTIONAL PRINCIPLES}

The EIT law adheres to two fundamental principles of tax jurisdiction: (1) global or worldwide taxation of resident taxpayers; and (2) territorial or source-based taxation of non-residents. The worldwide system of taxation is complimented by a direct and indirect foreign tax credit to provide relief from international double taxation, as well as by an anti-deferral rule or the controlled foreign corporation (CFC) rule (discussed below).

\section{INBOUND RULES}

Foreign investment in China predominantly takes the form of "direct investment”. Foreign-investment enterprises typically include Chineseforeign joint venture companies and wholly foreign-owned companies. These companies are generally "residents" in China as their place of incorporation must be in China under Chinese law. As such, a foreign investor is directly taxable in China only on the income received from the Chinese company by way of dividends, interests or royalties. The Chinese tax on such types of income is withheld by source at the standard rate of 20\% (EIT Law, Art. 4).

Foreign companies doing business in China through an establishment or site are taxable on income effectively connected to the establishment or site. The general rules for the computation of taxable income and tax payable are the same for a resident enterprise or an establishment or site of a non-resident enterprise (see sections 2.3 and 2.4 above). However, the tax incentives discussed above are generally not available to non-resident 
enterprises. There is no "branch tax", that is after-tax profit earned through an establishment or site is not subject to a second-level Chinese tax (unlike dividends received from a Chinese resident enterprise).

Portfolio foreign investment in China is subject to withholding taxes at the rate of $20 \%$ of gross payments. In addition to the typical forms of investment income (i.e., dividend, interest, rent and royalty), withholding tax is imposed on income from providing services in China or engaged in engineering projects (EIT Law, Art.38).

\section{Outbound Rules}

Chinese residents earning income from foreign courses are subject to the EIT. In case such income is taxable in the foreign source country, the EIT Law provides for a direct foreign tax credit and indirect foreign tax credit (EIT Law, Art. 23).

The direct foreign tax credit system operates on a worldwide basis. There is no distinction between business income and passive income in determining the limit on the foreign tax credit. The amount of the credit is limited by the amount of Chinese tax otherwise payable on the foreign income. Any excess credit may be carried forward for five years, but not refunded (EIT Regulations, Art.78).

For the first time, China allows an indirect foreign tax credit: a credit may be claimed for any foreign corporate income tax attributable to the dividends received by a Chinese corporate shareholder from a non-resident corporation that is controlled directly or indirectly by a Chinese resident (EIT Law, Art. 24). This indirect credit is available only if the Chinese resident owns more than $20 \%$ of the equity in the foreign company (EIT Regulations, Art.80).

\section{EFFECT OF TAX TREATIES}

The above rules under the EIT are subject to overriding provisions in China's bilateral tax treaties, and the "tax arrangement” with Hong Kong 
and Macao. Under Chinese law, tax treaties override domestic tax law in the case of any inconsistency (EIT Law, Art.58).

These treaties and arrangements inevitably reduce China's tax jurisdiction as a source country. This is most notable in three areas: (1) the definition of "permanent establishment", and (2) rate of withholding taxes; and (3) source rules.

The concept of “permanent establishment" is narrower under China's tax treaties by imposing a temporal threshold or excluding certain activities from giving rise to a permanent establishment. For example, Article 5 of the China-Canada Tax Treaty $^{25}$ provides that a building site, a construction, assembly or installation project or supervisory activities constitutes a permanent establishment only if it lasts more than 6 months, and that the furnishing of services, including consultancy services, constitutes a permanent establishment if it lasts more than 6 months within a 12 month period. Like other treaties, the China-Canada Treaty contains Article 5(6) of the OECD Model that excludes some places or sites which are deemed as "establishment or site" under the EIT from being a permanent establishment. ${ }^{26}$

The rate of a Chinese withholding tax is $20 \%$. This tax rate may be reduced by tax treaties. It can be concluded as follows:

25 Agreement Between the Government of the People's Republic of China and the Government of Canada for the Avoidance of Double Taxation and the Prevention of Fiscal Evasion with Respect to Taxes on Income ( hereinafter China-Canada Tax Treaty), concluded on May 12, 1986 in Beijing, entered into force December 29, 1986, effected January 1, 1987.

26 A fixed place of business is deemed not to include: (a) the use of the facilities solely for the purpose of storage, display or delivery of goods or merchandise belonging to the enterprise; (b) the maintenance of a stock of goods or merchandise belonging to the enterprise solely for the purpose of storage, display or delivery; (c) the maintenance of a stock of goods or merchandise belonging to the enterprise solely for the purpose of processing by another enterprise; (d) the maintenance of a fixed place of business solely for the purpose of purchasing goods or merchandise or for collecting information, for the enterprise; (e) the maintenance of a fixed place of business solely for the purpose of carrying on, for the enterprise, any other activity of a preparatory or auxiliary character; (f) the maintenance of a fixed place of business solely for any combination of activities mentioned in subparagraphs (a) to (e) provided that the overall activity of the fixed place of business resulting from this combination is of a preparatory or auxiliary character. 
- Dividends: $10 \%$ in most treaties; $5 \%$ under the treaties with Kuwait, Mongolia, Mauritius, Croatia, Slovenia, Yugoslavia, Sudan, Laos, Seychelles, South Africa, Barbados, Oman, Bahrain, Mexico, Brunei, Saudi Arabia; 8\% under the treaties with Egypt and Tunis; and $15 \%$ under the treaties with Norway, New Zealand, Australia, Brazil, Papua New Guinea. There is a split-rate with a lower rate for direct investment and a higher rate for other investments. Under the China-Canada tax treaty, for example, the withholding tax rate for the beneficial owners as a company directly holding no less than $10 \%$ voting rights of the payer is $10 \%$, while $15 \%$ of withholding tax is for other investments. ${ }^{27}$

- Interest: $10 \%$ in most treaties; $5 \%$ in China-Kuwait treaty; $7 \%$ in the China-United Arab treaty; $7.5 \%$ under the treaties with Jamaica, Cuba; and 15\% under the treaty with Brazil. Under the treaties with Austria, Israel, Venezuela, Saudi Arabia and Algeria, there is a split-rate with a lower rate for interests paid to banks or financial institutions, and a higher rate for others.

- Royalties: $10 \%$ in most treaties; $5 \%$ in the China-Cuba treaty; $7 \%$ in the China-Spain treaty; and $8 \%$ in the China-Egypt treaty. In the treaties with United Kingdom, Malaysia, Bulgaria, Luxembourg, The Philippines, Tunis, a lower tax rate is available for the industrial, commercial and scientific equipment, or advanced technology.

The source of capital gains is significantly narrower under tax treaties. For example, under Article 13 of the China-Canada Tax Treaty, gains from the disposition of shares of Chinese companies are not taxable in China unless the assets of the Chinese company consist mainly, directly or indirectly, of immovable property situated in China.

\section{G. ANTI-AVOIDANCE RULES}

The anti-avoidance rules contained in the EIT legislation are extensive, including transfer pricing rules, thin capitalization rules, controlled foreign corporation rules, and a general anti-avoidance rule. A special interest charge provides some real teeth for these rules.

${ }^{27}$ China-Canada Tax Treaty, ibid., Art.10. 


\section{TRANSFER PRICING}

The transfer pricing rule is the only anti-avoidance rule that existed in prior legislation. The EIT Law now codifies the "arm's length principle" as follows: "where a transaction between an enterprise and its related parties is not based on the arm's length principle, thereby reducing the taxable income of the enterprise or its related parties, the tax authority is empowered to make reasonable adjustments to the taxable income of the enterprise or its related parties” (EIT Law, Art.41).

A related "party" is not limited to an "enterprise". A partnership or individual that is not an "enterprise" under the EIT can be a related party (EIT Regulations, Art.109). A "related party” is an enterprise, organization or individual that has one of the following relationships with a taxpayer enterprise:

- direct or indirect control over such matters as funds, operation, purchase and sales;

- both are directly or indirectly controlled by the same third person;

- Other relationships due to associated interested.

The SAT Transfer Pricing Circular ${ }^{28}$ provides more details regarding these tests. An enterprise is considered to be related to another enterprise where:

- one enterprise directly or indirectly owns $25 \%$ or more of the shares of another enterprise;

- two enterprises are directly or indirectly owned or controlled by a third party with a $25 \%$ or more interest;

- an enterprise borrows from another enterprise and the amount of such loan accounts for $50 \%$ or more of the borrower's own capital, or an enterprise guarantees $10 \%$ or more of another enterprise's total loans;

- more than half of an enterprise's senior management (e.g. board members and managers, or even one executive board member) is

28 Tax Administration Rules and Procedures for Transactions between Associated Enterprises [1998] Guo Shui Fa, No. 59. 
appointed by another enterprise;

- an enterprise's production and/or operation activities totally rely on the provision of a specific right (e.g. patent and technology) by another enterprise in order to operate normally;

- an enterprise fully supplies or controls the supply of raw materials, parts, etc., to another enterprise for its productive operations;

- an enterprise's products, including prices and the transaction conditions, are totally controlled by another enterprise; or

- an enterprise has actual control of another enterprise's productive operations, trade activities and profits (this relationship includes family relationships and relatives).

The concept of "control" is undefined for the purpose of the transfer pricing rules. It appears to have a very broad meaning - both de jure control (direct and indirect) and de facto control. A similarly broad meaning is used for the purpose of the CFC rules (see below).

The arm's length methods that can be used in making transfer pricing adjustments include: ${ }^{29}$

- $\quad$ the comparable uncontrolled price method (CUP);

- the resale price method;

- the cost-plus method;

- $\quad$ the transactional net margin method (TNMM);

- the profit split; and

- $\quad$ any other arm's length methods.

There is no specific hierarchy mandated by law, although the order in which the methods are listed indicates some order of hierarchy. The SAT states in its Transfer Pricing Circular that the three traditional methods (CUP, resale and cost plus) are basic methods and should be chosen first.

"Other" arm's length methods can be used if none of the specific method is suitable (EIT Regulations, art.115). These other methods may be: (a) the profit level of other enterprises that are the same or similar to the taxpayer (which is essentially a comparable profit method); (b) the taxpayer' cost plus reasonable expenses and profit margins; (c) a reasonable proportion

29 EIT Regulations, supra note 5, Art.111. 
of the profit of the group of related companies (this appears to be a formulary-apportionment method); and (d) other reasonable methods of assessment.

Taxpayers can also use cost sharing agreements with respect to intangible property transactions (EIT Regulations, art.112). Such agreements must provide the tax authorities with relevant documentation to prove that the pricing is reasonable and that the shared costs are proportionate with the anticipated profits. Otherwise, the costs are not deductible.

Advanced pricing arrangements are recognized as valid agreements between the taxpayer and the tax authorities. ${ }^{30}$ The stated objectives are to reduce the cost of transfer pricing audits and inspections and to provide certainty for both taxpayers and the tax authority. The term of the APA is two to four years, which generally begins from the year in which an APA application is filed. As of March 2008, there are over 180 APAs concluded, including more than ten (10) bilateral APAs (involving Japan, Korea and the United States). There are no multilateral APAs yet. ${ }^{31}$

Contemporaneous documents and other documents in respect of related party transactions must be provided to the tax authorities (EIT Law, Art.114). These include contemporaneous documents in respect of related party transactions such as pricing, standards for determining expenditures, computation methods, explanatory notes; documents relating to resale (transfer) price or ultimate sale price in respect of the properties, use right of the properties, services of the related party transactions, etc.; information such as product price, pricing method, profit level, etc. that

30 Procedures and documentation requirements are set forth in the Transfer Pricing Circular as well as the APA Circular -- Guo Shui Fa (2004) No. 118.

31 The first bilateral APA was concluded in September 2005 between the taxpayer, the SAT and the Japanese National Tax Administration. The APA was negotiated between the taxpayer and the Shenzhen Local Tax Bureau, and approved under the mutual agreement procedure under the China-Japan tax treaty. A more recent bilateral APA was concluded between the Korean National Tax Service and SAT on 7 November 2007 regarding Samsung. The APA covers two Chinese subsidies of Samsung: one in Suzhou and another in Shandong. As the subsidiaries filed separate applications with their respective tax bureaus, this bilateral agreement is regarded as twin APAs from China's perspective. The period of time required to conclude a bilateral APA varies. The APA between Wal-Mart, SAT and the United States Internal Revenue Service took six months, whereas the one with Korea took more than two years. 
are comparable to the enterprise being investigated (EIT Regulations, Art.114).

\section{THIN CAPITALIZATION}

Interest expenses on "excessive debts" owed to related parties are not deductible under the thin capitalization rule (EIT Law, Art.46). According to the SAT Explanatory Notes on the EIT Law, there are two methods for determining whether an enterprise is "thinly" capitalized: a specified debt/equity ratio, and reasonable method. The term "debt to a related party" is defined to include debts provided to the taxpayer by a related party via a third party (e.g., a "back-to-back" loan), debts from an arm's length party, but guaranteed by a related party, and other types of indirect debt investments from a related party (EIT Regulations, Art.119). The acceptable debt/equity ratio is not specified in the EIT Regulations.

\section{THE CFC RULE}

The controlled foreign corporation rule is stated as follows (EIT Law, Art.45):

Where an enterprise that is established by a Chinese resident enterprise in a jurisdiction pays tax at a rate obviously lower than the tax rates as stipulated in Article 4 [of the EIT Law] and does not distribute its profits for reasons other than business needs, the amount of profit that should have been distributed to the Chinese shareholder is included in the income of the Chinese resident.

A foreign corporation refers to a non-resident corporation that is controlled by a Chinese resident. "Control" is defined to mean the ownership of more than $10 \%$ of voting shares and $50 \%$ of total shares of the foreign corporation, or effective control in terms of shares, funds, business management, purchase and sale, and other aspects of the foreign corporation (EIT Regulations, Art. 117). A foreign country's tax rate is "obviously lower" than the standard Chinese tax rate if it is lower than $50 \%$ of the Chinese rate (i.e., 12.5\%) (EIT Regulations, Art.118). 


\section{General ANTI-AVOIDANCE Rule (GAAR)}

The GAAR adopts the "reasonable business purpose" test: "Where an enterprise enters into an arrangement that has no reasonable business purpose, thereby reducing its taxable revenue or income, the tax authority has the power to make adjustments based on reasonable methods." (EIT Law, Art.47) It authorizes the Chinese tax authorities to make an adjustment if the GAAR applies. This is a strong signal of the tax authorities' growing scrutiny of tax-avoidance schemes. Presumably, this rule applies when a transaction avoids the application of specific antiavoidance rules.

\section{Penalty for Avoidance Transactions}

The application of any of the above anti-avoidance rules may result in an adjustment to the taxable income, resulting in additional tax liability. Readjustments can be made at any time during the ten-year period starting in the year in which the avoidance transaction takes place. If additional tax is payable because of the adjustments, a "penalty" is imposed in the form of "additional interest” (EIT Law, Art. 48). This interest is specified to be 5 percentage points plus the benchmark lending rate published by the People's bank of China for the year in which tax payment occurs.

\section{H. ADMINISTRATION}

Administrative matters related to the EIT are contained in the Tax Administration and Collection Law. ${ }^{32}$ The EIT Law does clarify that a "taxation year" is the calendar year (Art. 51) and that no consolidation is allowed for enterprise groups (unless specifically authorized by the State

${ }^{32}$ Law of the People's Republic of China on Administration of Tax Collection, promulgated by the 27th session of the seventh National People's Congress, September 4, 1992; amended in the 12th session of the eighth National People's Congress, February 28, 1995; amended in the 21st session of the ninth National People's Congress, April 28, 2001. 
Council) (Art.53).

\section{SUPPLEMENTARY PROVISIONS}

Transitional rules are provided to foreign-investment enterprises that enjoy preferential tax treatment under the previous tax system (EIT Law, Art.57). A five-year gradual transition to the new rates is allowed for foreign-investment enterprises that had been taxed at much lower effective rates. Foreign-investment enterprises that were eligible for a fixed-period of tax holiday under the previous tax regime are allowed to exhaust the tax holiday before subjecting to the new regime. Tax holidays that begin in the first-year of making a profit, on the other hand, are terminated if the taxpayer has failed to make any profits before 2008. The preferential period of these tax holidays shall start in 2008 and end in 2013. A qualifying enterprise for these transition rules must have been approved to be set up before March 16, 2007, which was the enactment date of the EIT Law (EIT Regulations, Art.131).

\section{TRANSFORMATIVE AsPECTS}

\section{A. FORM, ORGANIZATION AND TERMINOLOGY}

In many ways, the EIT is a transformed tax. Its title - "Enterprise Income Tax Law of the People's Republic of China" -conveys a sense of maturity by dropping out the previous qualifiers for enterprises, such as "Foreigninvestment enterprises" and "foreign enterprises", and replacing "Interim Regulations"33 with "Law". The EIT Law is more extensive and better organized. For example, the JVIT Law (1980) contained 18 articles, the Foreign-investment Enterprise and Foreign Enterprise Income Tax Law (1991) contained 30 articles, the EIT Law contains 60 articles which are organized into 8 chapters.

${ }^{33}$ Interim Regulations of the People's Republic of China on the Enterprise Income Tax, promulgated by the State Council on 14 December 1993, abolished after the enactment of the EIT Law. The Interim Regulations were applied to domestic enterprises. 
New principles, concepts and rules are found in each chapter of the EIT Law and EIT Regulations. For example, 28 out of 130 articles of the EIT Regulations are brand new, and another 21 articles are substantially new. Only 5 articles (Arts.18, 21, 55, 58 and 59) are unchanged from the previous regime.

The EIT legislation adopts new terminologies, such as:

- "resident” and “non-resident” (EIT Law, Art.2);

- “place of effective management” (EIT Law, Art.2);

- “dividend” (EIT Law, Art. 6) (this concept was previously expressed as "profit" or "li run" in Chinese); ${ }^{34}$

- “fair market value” (EIT Regulations, Art. 13);

- “supplementary pension plans”, “supplementary health insurance plans” (EIT Regulations, Art.35);

- “non-profit organizations” (EIT Law, Art.26);

- " "biological assets” (EIT Regulations, Art.62);

- “arm’s length principle” (EIT Law, Art.41);

- "cost sharing agreement” (EIT Law, Art.41);

- “advance pricing arrangement” (EIT Law, Art.41);

- “controlled foreign corporations” (EIT Law, Art.45; EIT Regulations, Art. 117);

- “thin capitalization”, “debt” and "equity” (EIT Law, Art.46; EIT Regulations, Art.119); and

- “reasonable business purpose” (EIT Law, Art.47).

Compared to the massive Canadian Income Tax Act (the print version weights over one kilogram), ${ }^{36}$ the EIT Law and Regulations still appear

${ }^{34}$ E.G., Art.19, Detailed Rules and Regulations for the Implementation of the Income Tax Law of the People's Repulic of China for Enterprises with Foreign Investment and Foreign Enterprises, issued by the State Council on 30 June 1991(hereinafter "FIE Tax Regulations").

${ }^{35}$ The FIE Tax Law (Art.13), supra note 1, and FIE Tax Regulations, ibid., (Art.52-57) address transfer pricing issues, but did not use or define "arm's length principle" as a term.

${ }^{36}$ Ipsco Inc. v. R., [2002] 2 C.T.C. 2907, 2002 D.T.C. 1421 at para. 26 (T.C.C.). For more discussion of the structural and drafting features of the Canadian Income Tax Act, see Peter Hogg, Joanne Magee and Jinyan Li, Principles of Canadian Income Tax Law (6 $^{\text {th }}$ ed) (Toronto: Carswell, 2008), ch.1. 
simplistic and rudimentary. However, given the short history of modern income taxation in China, the EIT legislation contains the necessary framework and elements for further developments.

\section{B. SUBSTANTIVE TRANSFORMATION}

The transformation of the system goes way beyond form and terminology. Each major element of the system contains new, and sometimes "revolutionary", substantive rules. Subjecting all "enterprises" to the EIT ends the dual-track system of enterprise income taxation in China, thereby terminating the systematic tax discrimination against domestically-owned enterprises. $^{37}$ The standard rate of $25 \%$ symbolizes China's shift in tax competition strategy from FDI-specific measures to general lower tax rate. The deductibility rules from determining taxable income provide more certainty for taxpayers with "bright-line" tests (such as those on entertainment expenses, advertising costs) as well as deliver tax subsidies for social purposes (such as contributions to employer-sponsored pension plans, health insurance plans, housing fund, and expenditures on hiring disabled workers).

The tax incentive measures are more streamlined, emphasising sustainable economic development. The subsidized investments are selected on the basis of their nature and potential positive externalities on economic development as opposed to the previous formalistic approach (who owns the enterprise and where the enterprise is located). The format of providing tax incentives is more aligned with the policy objective of the tax incentive. For example, a lower rate is applicable to small, low-profit enterprises, which are presumably important in job-creation and innovation and can use the after-tax profit for reinvestment, but get no tax

${ }^{37}$ For more discussion on Chinese FDI-specific tax incentives, see Andrew Halkyard and Ren Linghui, "China's Tax Incentive Regimes for Foreign Direct Investment: An Eassonian Analysis", paper given at a symposium at Queen's University entitled "Globalization and the Impact of Tax on International Investments", see http://law.queensu.ca/announcements/taxSymposiumAnnouncement.html; Jinyan Li, "The Rise and Fall of Chinese Tax Incentives and Implications for International Tax Debates" (Florida Tax Review forthcoming; see CLPE Research Paper 5/2008, available at http://ssrn.com.abstract=1087382); and Ryan Chang and Jeffery Kadet, "China Issues Implementation Rules on Tax Unification” (2007) Tax Notes International 1099-1105. 
subsidy before becoming profitable. Large enterprises also receive tax subsidies in the form of "exaggerated deductions" or exemptions in respect of research and development expenditures, providing employment for the disable, or utilizing "green" technologies. The tax incentives encourage long-term, sustainable investments as opposed to encouraging "footloose" firms ${ }^{38}$ as under the previous "tax holidays". The new incentive measures overcome the problems of "round tripping"39 by abolishing FDI-specific tax holidays.

The international tax rules (discussed above) and new anti-avoidance rules targeting "inbound transactions" (such as transfer pricing, thin capitalization) and those targeting "outbound" transactions (notably the CFC rules) recognize China's new position in the global economy as not only a major recipient of FDI, but also an emerging exporter of capital and the associated tax policy issues.

\section{TRANSFORMATION THROUGH HYBRIDIZATION}

\section{A. INTERNATIONAL TAX NORMS}

Since the very beginning of the modern tax system, China has resisted "cloning" or "transplanting" the tax law of any specific foreign country for several possible reasons. First, no country resembles China close enough

\footnotetext{
38 "Footloose" investors refer to investors that continuous reinvest in loss-making enterprises. To continue enjoying FDI tax holidays, some foreign investors may postpone making profits or reinvest a new enterprise once tax holidays are over. See $\mathrm{Li}$, supra note 37.

${ }^{39}$ Easson argues that whenever only foreign investors enjoy tax incentives, domestic investors have the motivation to round tripping their capital abroad in order to gain benefits from these tax incentives. In China, it is estimated that the "round tripping" FDI ratio is likely to be around 40 percent of recorded flows or within the range of 30 percent to 50 percent. See Alex J. Easson, Taxation of Foreign Direct Investment (United Kingdom: Kluwer law International Ltd, 1999); Xiao Geng, Round-Tripping Foreign Direct Investment and the People's Republic of China (Asian Development Bank Institute: Japan, 2004); China Daily, Investment outflows to tax havens, People's Daily Online, June 22, 2004, available at http://english.peopledaily.com.cn/200406/22/eng20040622_147138.html , visited in 31 July 2007.
} 
to be used as a model. Second, when it came to borrowing foreign tax ideas, Chinese policy makers preferred to let "hundreds of flower blossom at the same time" so that useful elements from various regimes could be selected to serve China's needs. The recent history of China made copying any Western country's laws politically sensitive for policy makers. Third, Western countries are "harmonizing" their international tax rules in recent years (e.g., CFC rules, thin capitalization rules, transfer pricing, withholding taxes, jurisdictional rules, etc.). Fourth, because China needed to compete for FDI with other developing countries, the tax policy of these countries must be studied, compared, and taken into consideration by Chinese policy makers. Therefore, "international tax norms" became a convenient justification for adopting anything not-home-grown.

On the basis of the SAT Explanatory Notes, the notion of "international tax norms" seems to encompass ideas, rules, principles, and practices from the following sources:

- OECD Model Tax Convention and Commentaries;

- UN Model Tax Convention;

- OECD Transfer Pricing Guidelines;

- statutory rules of one or more foreign countries (including, but not limited to OECD Member countries);

- case law of foreign countries (particularly that of common law jurisdictions);

- administrative rulings and practices of foreign countries; and

- World Trade Organization agreements.

International tax norms are used to justify not only pure "international" tax rules, but also general rules. The most direct adoption is perhaps in the area of anti-avoidance rules, especially transfer pricing rules and thin capitalization rules. The adoption of the place of effective management as a test for residency is predominantly rationalized on ground of international tax norms. In its Explanatory Notes, the SAT cited the domestic statutory rules in the United States, Sweden, Mexico, UK, Japan, France, Germany, Italy, Australia, Belgium, Denmark, India, Thailand (as examples of adopting the place of incorporation test); France, UK, Germany, Canada, Argentina, Egypt, Malaysia, Ireland and Luxembourg (as examples of adopting the place of management and control test); and the OECD Model Tax Convention and Commentaries on Article 4. 
General tax rules that are explained on ground of international tax norms include the following:

- The standard tax rate and rate of withholding taxes (which are believed to be internationally competitive); ${ }^{40}$

- The deduction of charitable donations up to $12 \%$ of the annual profit is "referenced to common international practice"; (SAT Explanatory Notes on EIT Law, Art.9);

- The cost of creating goodwill by the taxpayer is non-deductible because, among other reasons, "most countries in the world do not allow the amortization of such costs" (SAT Explanatory Notes on EIT Law, Art.12);

- One of the explanations for prohibiting the use of LIFO (lastin, first-out) method of computing the cost of goods sold is "even free jurisdictions such as Hong Kong limit the use of LIFO and many developed countries limit LIFO in tax law and accounting rules” (SAT Explanatory Notes on EIT Law, Art.15).

- The five-year loss carry-forward rule is adopted because "the majority of developed and developing countries adopt loss carry-forward method for 4, 5, 8 or even 10 years, and the 5year carry-forward rule is the same as that in Germany, Italy, Spain, Portugal, Denmark, Korea, Argentina, etc.” (SAT Explanatory Notes on EIT Law, Art.18).

- In explaining the non-taxation of non-profit organizations, the SAT cited the US Internal Revenue Code and "international norm” (SAT Explanatory Notes on EIT Law, Art.26).

- The reduced rate for small and low-profit enterprises "is referenced to international common practice” and the examples of foreign practice for assessing "small enterprise" include the United States adopting the standard of sales and number of employees, France using the number of employees as a basic standard, Germany using annual sales and number of employees, and Japan using capital and number of employees (SAT Explanatory Notes on EIT Law, Art.28).

\footnotetext{
${ }^{40}$ Some EU countries abolish of FDI-specific tax incentives and adopt a reduced statutory corporate tax rate: see OECD, Tax Effects on Foreign Direct Investment: Recent Evidence and Policy Analysis (OECD: Paris, 2007), at 80-81.
} 
- The "additional deduction" for research and development and job creation for disabled workers is "commonly used by countries in the world" in order to encourage investment in specific areas (EIT Law, Art.30).

- The adoption of the investment tax credit method for encouraging production by way of comprehensive utilization of resources is, in part, because it does not run afoul of the national treatment principle under the WTO (SAT Explanatory Notes on EIT Law, Art.34). ${ }^{41}$

\section{B. CHINESE INNOVATIONS}

Many provisions of the EIT Law and Regulations are unique and innovative, most of which are intended to protect the tax base. Some examples in the international tax area include:

- Foreign partnerships are "taxpayers" for the purpose of the EIT, whereas domestic partnerships are not (EIT Law, Art.2).

- A resident enterprise cannot deduct losses attributable to a foreign branch (EIT Law, Art.17).

- The source of capital gains from the disposition of shares of Chinese companies is deemed to be China (EIT Regulations, Art.7).

- The source of income from insurance premiums collected by a non-resident enterprise from Chinese residents is China (EIT Regulations, Arts.7 and SAT Explanatory Notes on EIT Regulations, Art.7).

- The use of "formulary apportionment" and other reasonable methods to allocate profits from related-party transactions to a Chinese taxpayer (EIT Law, Art.44 and EIT Regulations, Art.115). ${ }^{42}$

Other "innovations" include the rule that excludes dividends effectively

${ }^{41}$ Previously, the investment tax credit was given to enterprises that purchase Chinamade equipment, which was challenged by the United States and other countries under the WTO regime. See SAT Explanatory Notes on EIT Law, Art.34.

${ }^{42}$ This method was used for assessing domestic enterprises under the previous system. It is now made applicable to cross-border related party transactions: see SAT Explanatory Notes on EIT Law, Art.44). 
connected with a Chinese establishment of a non-resident enterprise from income (EIT Law, Art.26). The rationale for this rule is to prevent double taxation in China, which, as discussed earlier, does not seem to make much sense.

Compared to other developing countries competing for FDI inflows, China is "innovative" in abandoning the FDI-specific tax incentives. It is conceivable that many FIEs continue to enjoy tax incentives under the new system. However, FIEs will have to qualify for the incentives because of the nature of investment, not just because of the form of ownership or location in a special area.

\section{CHINESE LeGACIES}

The legacies of economic transition and Chinese culture find their way into the EIT legislation. For example, in computing taxable income, a taxpayer may deduct a reasonable amount of wages and salaries, which include basic wages, bonuses, allowances, subsidies, year-end wage increase, compensation for over-time work and other expenses related to the employment of workers (EIT Regulations, Art.34). Under general accounting principles, such costs are clearly deductible in computing profit. That is why the Canadian Income Tax Act does not have a specific rule for the deductibility of wages and salaries. In China, on the other hand, wages and salaries of workers for Chinese-owned enterprises (especially state-owned) have been strictly regulated by the government. As late as 2006, the government allowed the standard monthly salary be raised from 800 yuan to 1600 yuan and enterprises could deduct only the standard amounts. ${ }^{43}$ Enterprises often pay workers above the regulated amounts, but were unable to deduct the payments. That was one of the causes for tax discrimination between Chinese-owned and foreigninvestment enterprises because the latter was not subject to any wage controls. Article 34 of the EIT Regulations allows full deduction for wages and salaries, as long as the amount is reasonable, ${ }^{44}$ thereby eliminating the

43 SAT Officials Answer Media Questions about Tax Deductible Wages for Domestic Enterprises, 19 October 2006, available at the SAT website: www.chinatax.gov.cn

${ }^{44}$ To the extent that wages remain regulated by the government, the "reasonable" amount may be limited to the specified amount. As the labour market in China becomes more 
tax discrimination. Viewed in this light, this rule represents a great step forward in Chinese tax policy.

The tax incentive provisions under the two previous enterprise income tax laws were vastly different, causing serious discrimination against domestically-owned enterprises. Unlike the case of wages and salaries, the EIT Law does not expand the treatment of foreign-investment enterprises to domestically-owned enterprises. Instead, it provides a brand new regime for both types of enterprises. However, the legacies of the previous regimes are notable. Tax incentives remain a key part of the new tax system. High-tech industries, infrastructure projects, agricultural, fishing, forestry and animal husbandry continue to be eligible for tax incentives.

Another Chinese legacy is the extent of discretion given to the tax authorities, especially in the area of approving the qualifications for tax relief. For example, Article 35 of the EIT Law provides detailed measures for implementing tax incentives are to be introduced by the State Council. The State Council promulgated chapter 4 of the EIT Regulations, specifying the details for tax incentives. The EIT Regulations, in turn, authorize the SAT, Ministry of Finance and other relevant government departments to provide further details for actually implementing most of the tax incentive measures.

It is also customary in Chinese legal drafting to have a "residual" clause that authorizes the government to determine "other" amounts or issues. Examples include:

- “Other items” of exempt income (EIT Law, Art.7);

- “Other capital expenditures” that cannot be depreciated (EIT Law, Art.11);

- "Expenditures on other intangible assets" that cannot be amortized (EIT Law, Art.12);

- "Other income" earned by a non-resident may be considered taxable income (EIT Law, Art.19);

- "Other tax incentives” to be introduced by the State Council to

liberalized, the degree of regulation is declining. For more discussion on wage control in China, see Andrew G. Walder, "Markets and Income Inequity in Rural China: Political Advantage in an Expanding Economy” (2002) Vol. 67, No. 2, American Sociological Review, 231-253. 
promote the national economic and social development or to avoid major impact to enterprise business activities caused by sudden incidents (EIT Law, Art.36);

- "Other method for assessing taxable income of related parties" if the taxpayer fails to provide documentation regarding related party transactions or if the documentation is fraudulent, incomplete, or untruthful (EIT Law, Art.44).

Compared to its predecessors, however, the EIT Law is a vast improvement in reducing the scope of "administrative" decision-making powers. For example, although the qualifying conditions for many tax incentives are determined by the SAT, Ministry of Finance or other departments of the government, these conditions are published as "administrative rules". Under Chinese law, such "administrative rules" are part of the tax legislation. ${ }^{45}$ Under the FIE Tax Law, many tax incentives required "pre-approval" by the tax administration before a taxpayer could receive the incentive. ${ }^{46}$ The EIT regime clearly provides taxpayers with more certainly and predictability, as the new rules are far more detailed and transparent than any tax rules in China's modern history.

\section{SOME THOUgHTS ON CODIFYING INTERNATIONAL TAX NORMS}

The Chinese EIT has strong "international" features in terms of structure, terminology, and substantive rules. In fact, it may read like a summary of

\footnotetext{
45“Provisional regulations" or "interim rules" are promulgated by the State Council (similar to the executive branch of government in the West), the Ministry of Finance or SAT under the delegated power of legislation. All of these have the force of law. See more discussions in Jinyan Li, "Development and Tax Policy: Case Study of China" (2006), submitted for presentation at $1^{\text {st }}$ INTR Conference.

${ }^{46}$ See FIE Tax Regulations, supra note 34, Arts. 67, 70, 72, 73, 74, 75, 80, 81 and FIE Tax Law, supra note 1, Art.19. For example, to receive tax incentives, export-oriented enterprises and enterprises in special zones and areas need "pre-approval" by tax administrations. The following documents must be submitted by foreign investment enterprises with the application for export-oriented status: copies of the original approval documents and business license; the audit report on the export product foreign exchange revenue and expenditure for the year before the application for confirmation.
} 
a tax law in Canada or another Western country. Compared to its predecessors, the EIT legislation makes the Chinese tax system more neutral, equitable, more transparent and predictable, and arguably more internationally competitive. It is too early to say whether such highly hybrid system of taxation, which looks good on paper, can work well in practice. We have been impressed with what the SAT has been doing in "educating" tax officials and the public about the new legislation.

International tax norms clearly provide a convenient and convincing rationale for tax reform in many cases. The increasing integration of Chinese economy with the global economy naturally requires China's corporate tax system to assimilate, as much as possible, that of other countries which may be exporting capital to China, importing capital from China, or competing with China for FDI inflows.

Incorporating international tax norms into Chinese legislation has some challenges. One is to obtain complete and accurate information on the various sources of international tax norms. Students of international and comparative taxation know the inherent difficulties in this task. Translating the foreign materials into Chinese language is another daunting task.

Another challenge is the interpretation and understanding of the international norms. Viewed at a general level, an international tax norm may have an obvious meaning. Upon closer examination, however, many "norms" have various nuanced meanings. Like an onion, the appearance of "international tax norm" may not reveal its true "taste" or "smell" without peeling off the layers.

A third challenge is the selection of international tax norms for transplantation. Major determinants are probably local legal and institutional conditions. The CFC rule has been around for over three decades, but China did not adopt it until 2007 because it was irrelevant to China when outbound investment was insignificant. Another example is the use of the term "dividend." This term was not used in the 1980 JVIT Law or the 1991 FIE Tax Law because FIEs or Chinese enterprises were not necessarily organized in the form of companies. In fact, Chinese company law did not in 1980 or 1991. Now that Company Law has been implemented for a number of years and the notion of "dividend" is better 
known in China, “dividend” is used in the EIT Law.

The fact that Chinese courts do not have the general power of interpreting tax legislation means that Chinese tax legislation must "codify" commonlaw principles. One example is the meaning of "corporate residence". In Canada, this is determined by case law to mean the "place of central management and control"47. The meaning of "place of central management and control" is generally found to be the place where the board of directors meet and make decisions. Another example is the general anti-avoidance rule. In common-law countries, there are judicial anti-avoidance rules (such as the "substance over form" doctrine", the business purpose test, or sham doctrine) that function as general antiavoidance rules. Because Chinese courts function very differently from courts in Canada and many other countries, common-law tests or rules must be codified in the legislation. Such codification has its limitations, which is why the United Kingdom and the United States do not codify them. It is thus particularly interesting to see how common-law based international tax norms take their roots in China.

${ }^{47}$ See Jinyan Li, Arthur Cockfield and Scott Wilkie, International Tax in Canada: Principles and Practices (Lexis, 2006), ch.4. 